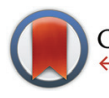

CrossMark

\&lick for updates

Cite this: Org. Chem. Front., 2016, 3, 957

Received 12th May 2016,

DOI: $10.1039 / c 6 q 000198$ j

rsc.li/frontiers-organic
Accepted 7th June 2016

\section{Synthesis of unsymmetrical NCN' and PCN pincer palladacycles and their catalytic evaluation compared with a related SCN pincer palladacycle $\uparrow$ t}

\author{
Gavin W. Roffe, ${ }^{a}$ Graham J. Tizzard, ${ }^{\mathrm{b}}$ Simon J. Coles, ${ }^{\mathrm{b}}$ Hazel Cox ${ }^{\mathrm{a}}$ and \\ John Spencer*a
}

1-(3-(Pyridin-2-yl)phenyl)methanamine derivatives have been synthesized and underwent $\mathrm{C}-\mathrm{H}$ bond activation to afford unsymmetrical NCN' pincer palladacycles, which were characterised in the solid state. 2-Pyridinyl-phenol and -benzyl alcohols were then used as precursors to unsymmetrical PCN pincer palladacycles. Catalytic applications, where the palladacycle remains in the $\mathrm{Pd}(॥)$ state, have been carried out and show good activity and selectivity.

\section{Introduction}

Palladacycles contain a covalent $\mathrm{Pd}-\mathrm{C}$ bond intramolecularly stabilised by a coordinating group such as an amine, phosphine or thioether and have been extensively studied since their discovery in the mid-1960s. ${ }^{1}$ Pincer palladacycles, where a tridentate ligand can coordinate to palladium were first synthesized by Shaw and Moulton in 1976. ${ }^{2}$ However, the field of palladacycle-mediated catalysis only truly gathered momentum after the seminal discovery by Herrmann and Beller et al. ${ }^{3,4}$ that their eponymous palladacycle (Fig. 1) was highly active in catalytic $\mathrm{C}-\mathrm{C}$ bond coupling reactions. Since, a number of

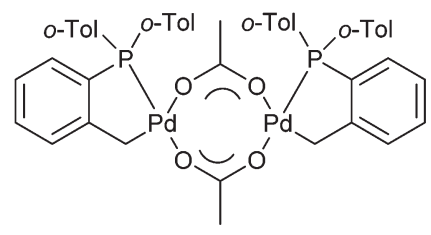

Fig. 1 Herrmann-Beller palladacycle. reviews and books have been published covering the wide array of catalytic applications..$^{5-14}$

The majority of pincer palladacycles are symmetrical, such as I (Fig. 2). ${ }^{15}$ However, unsymmetrical analogues such as II (Fig. 2) ${ }^{16}$ have been explored, ${ }^{17}$ and may provide a greater opportunity to fine tune catalysis due to the potential hemilability of the ligand ${ }^{18}$ and the ability to influence catalytic activity by altering the steric and electronic properties of the donor atoms. ${ }^{19,20}$

The synthesis of NCN pincers can be complicated compared with the analogous PCP and SCS pincers due to the hardligand (amine) soft-acid (metal) mismatch between palladium and nitrogen. This results in competition in forming the kinetic product III or the thermodynamic pincer product IV (Scheme 1). ${ }^{21}$ Hence, incorporating functional groups in the mutual ortho position such as $\mathrm{SiMe}_{3}$ or $\mathrm{Br}$ can be beneficial in their synthesis, compared with $\mathrm{C}-\mathrm{H}$ activation routes. $^{8}$ However, this is less attractive synthetically, since an additional step is required in making the functionalised ligand.

Examples of unsymmetrical PCN pincer palladacycles (Fig. 3) are synthesised by $\mathrm{C}-\mathrm{H}$ bond activation or chloropalla-<smiles>CN1CCC2=C(Cl)CN(C)[P@]21Cl</smiles>

II
Fig. 2 (I) symmetrical, $\mathrm{NCN}$, and (II) unsymmetrical $\mathrm{NCN}^{\prime}$ pincer palladacycles. 


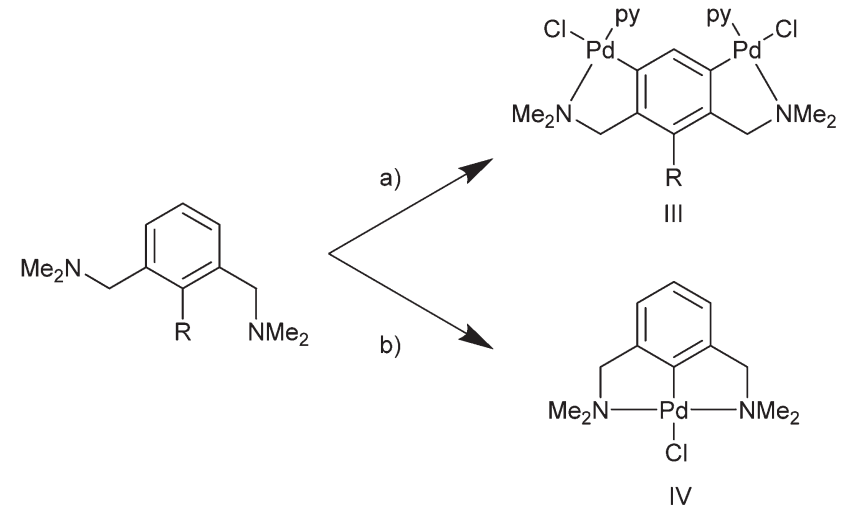

Scheme 1 py = pyridine (III) kinetic product, (IV) thermodynamic product. (a) (i) $\mathrm{R}=\mathrm{H}$; $\mathrm{Pd}(\mathrm{OAc})_{2}, \mathrm{MeOH}_{1} \mathrm{NEt}_{3}$, (ii) $\mathrm{LiCl}$, (iii) $\mathrm{R}=\mathrm{SiMe}_{3}$. py. (b) $\mathrm{Li}_{2}\left[\mathrm{PdCl}_{4}\right]$.
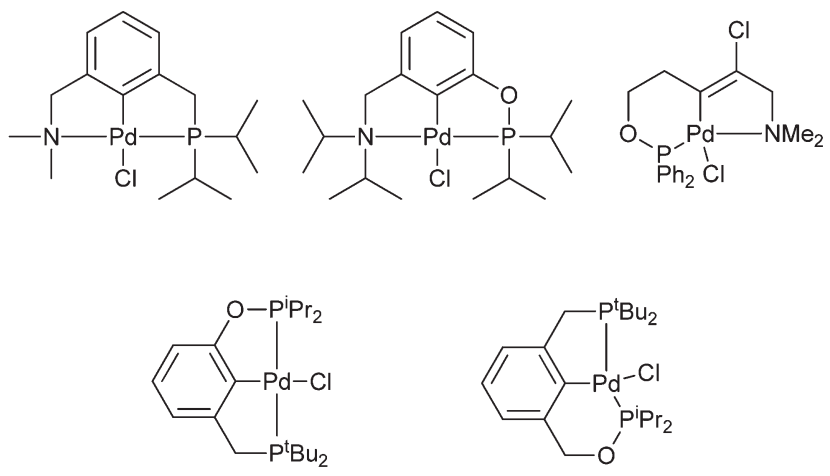

Fig. 3 Unsymmetrical PCN, and P'CP pincer palladacycles.

dation. ${ }^{16,22,23}$ A potential route to phosphorus containing palladacycles is via phenolic or benzylic alcohols, such as that by Eberhard et al., ${ }^{24}$ in the formation of mixed 5-,6-membered

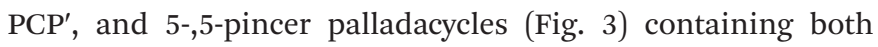
phosphine and phosphinite groups.

Palladacycles normally act as a reservoir of catalytically active $\operatorname{Pd}(0)$ species in applications such as the SuzukiMiyaura/Heck reaction. ${ }^{25,26}$ Other catalytic applications of pincer palladacycles utilise the palladium in its Pd(II) oxidation state, retaining its ligand structure, and are more likely to take advantage of the tuning abilities of the unsymmetrical ligand design. The use of pincer palladacycles as a Lewis acid catalyst in an aldol condensation (Scheme 2) demonstrated the ability to change the stereochemical outcome of the reaction depending on the ligand donor atoms. ${ }^{27}$ Another application utilising pincer palladacycles in $\mathrm{Pd}(\mathrm{II})$ catalysis, is in the coupling of vinyl epoxides and boronic acids using a symmetrical SeCSe palladacycle (Scheme 3). ${ }^{28}$

Unsymmetrical pincer palladacycles are relatively rare and their synthesis and that of their respective ligands often poses a greater challenge than for their symmetrical counterparts. Given some distinct advantages of employing unsymmetrical pincer palladacycles in catalytic applications, ${ }^{17}$ such as the<smiles>P=[PH]1(Cl)(c2ccccc2)Cc2cccc1c2P</smiles>

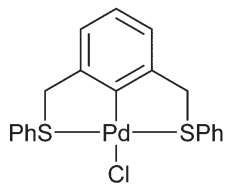

SCS<smiles>Pc1cccc2c1P(P)(Cl)(Pc1ccccc1)C2</smiles>

PCP

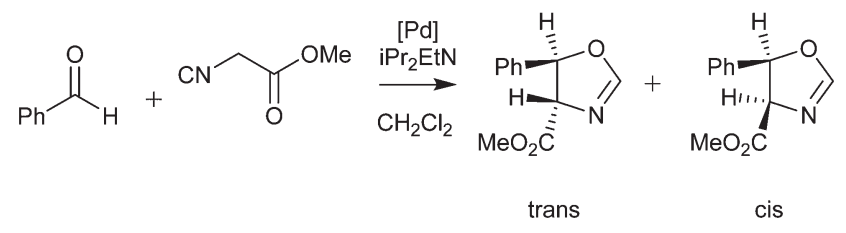

Scheme 2 Aldol condensation catalysed by pincer palladacycles.
Scheme 3 Vinyl epoxide and boronic acid coupling.

tandem catalysis reported by Szabó et $a{ }^{27}$ recent work in our group has focused on a robust synthetic route to useful, modular unsymmetrical ligands and their pincer palladacycles. ${ }^{29}$ The present work is focused on the synthesis of several new unsymmetrical nitrogen-based pincer ligands, denoted $\mathrm{NCN}^{\prime}$, their respective palladacycles, phosphinite PCN pincer palladacycles, and catalytic evaluation in aldol condensation and vinyl epoxide coupling reactions in comparison to a related SCN pincer palladacycle.

\section{Results and discussion}

\section{NCN' ligand synthesis}

The simple biaryl motif $\mathbf{1}$ was deemed to be a potentially useful precursor to $\mathrm{NCN}^{\prime}$ pincer ligands. 1 was formed via a Suzuki-Miyaura (SM) coupling and several catalysts, $\mathrm{Pd}\left(\mathrm{PPh}_{3}\right)_{4}$, $\mathrm{Pd}(\mathrm{dppf}) \mathrm{Cl}_{2}, \mathrm{Pd}(\mathrm{OAc})_{2}$ and Buchwald's XPhos Pd G2 catalyst $^{30}$ were trialled in order to optimise its yield (Table 1). It was found that $\mathrm{Pd}(\mathrm{dppf}) \mathrm{Cl}_{2}(\mathrm{Pd}-118)$ was the catalyst of choice utilising microwave-mediated (MW) synthesis (Table 1, entry 4).

Reductive amination of $\mathbf{1}$ with $\mathrm{HNMe}_{2} \cdot \mathrm{HCl}$ was attempted in order to synthesise the requisite unsymmetrical $\mathrm{NCN}^{\prime}$ ligand with the dimethyl amine and pyridine groups ideally placed to promote $\mathrm{C}-\mathrm{H}$ activation towards the corresponding palladacycle. Initially sodium triacetoxyborohydride ${ }^{31}$ proved unsuccessful although the use of titanium isopropoxide/ sodium borohydride $^{32}$ furnished the product $2 \mathbf{a}$ in $81 \%$ yield (Scheme 4). Next, we attempted reductive aminations with $\mathrm{NEt}_{2} \mathrm{H}$ using both of the above conditions but to no avail. 
Table 1 Optimisation of the SM coupling to form biaryl ligand backbone 1

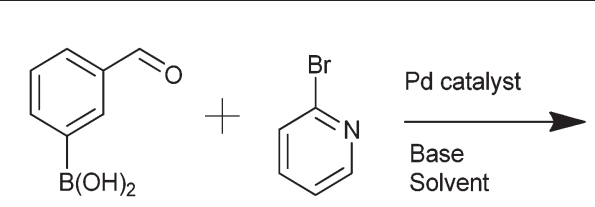

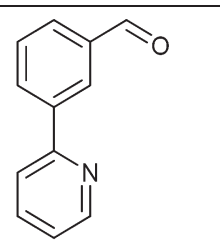

1

\begin{tabular}{|c|c|c|c|c|}
\hline Entry & Catalyst & Base & $\begin{array}{l}\text { Reaction } \\
\text { conditions }\end{array}$ & $\begin{array}{l}\text { Isolated } \\
\text { yield } / \%\end{array}$ \\
\hline 1 & $\mathrm{Pd}\left(\mathrm{PPh}_{3}\right)_{4}$ & $1 \mathrm{M} \mathrm{Na}_{2} \mathrm{CO}_{3}$ & A & 65 \\
\hline 2 & $\mathrm{Pd}\left(\mathrm{PPh}_{3}\right)_{4}$ & $1 \mathrm{M} \mathrm{Na}_{2} \mathrm{CO}_{3}$ & $\mathrm{~B}$ & 72 \\
\hline 3 & $\mathrm{Pd}\left(\mathrm{PPh}_{3}\right)_{4}$ & $1 \mathrm{M} \mathrm{Na}_{2} \mathrm{CO}_{3}$ & $\mathrm{C}$ & 58 \\
\hline 4 & $\mathrm{Pd}(\mathrm{dppf}) \mathrm{Cl}_{2}$ & $1 \mathrm{M} \mathrm{Na}_{2} \mathrm{CO}_{3}$ & C & 79 \\
\hline 5 & $\mathrm{Pd}(\mathrm{OAc})_{2}$ & $1 \mathrm{M} \mathrm{Na}_{2} \mathrm{CO}_{3}$ & $\mathrm{C}$ & 37 \\
\hline 6 & Buchwald XPhos Pd G2 & $0.5 \mathrm{M} \mathrm{K}_{2} \mathrm{PO}_{4}$ & $\mathrm{C}$ & 22 \\
\hline
\end{tabular}

$\mathrm{A}=$ thermal, $85^{\circ} \mathrm{C}, 18 \mathrm{~h} . \mathrm{B}=$ thermal, $85^{\circ} \mathrm{C}, 48 \mathrm{~h} . \mathrm{C}=\mathrm{MW}, 150{ }^{\circ} \mathrm{C}$, 20 min. Entries 1-5, $4 \mathrm{~mol} \%$ catalyst, $1: 2: 1$ base : toluene: EtOH. Entry 6,2 mol\% catalyst $1: 2$ base : THF.

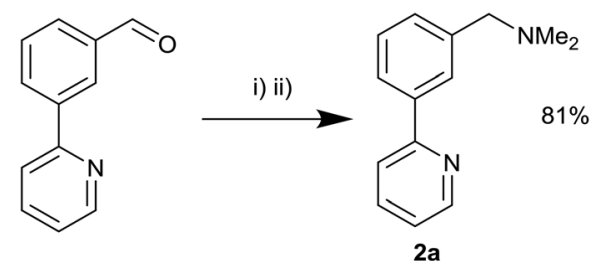

Scheme 4 Reductive amination procedure. (i) $\mathrm{Ti}\left(\mathrm{O}^{\mathrm{i}} \mathrm{Pr}\right)_{4}, \mathrm{EtOH}, \mathrm{NEt}_{3}$, $\mathrm{NHMe}_{2} \cdot \mathrm{HCl}$. (ii) $\mathrm{NaBH}_{4}$.

Given that the reductive amination procedure proved ineffectual, an alternative synthesis was devised. In previous work, ${ }^{29}$ we have shown the synthesis of the benzylic bromide 4, via benzylic alcohol 3 (Scheme 5) can allow late stage diversification via nucleophilic substitution by sulphur nucleophiles. ${ }^{29}$ Hence, the corresponding nucleophilic displacement of 4 was undertaken with nitrogen nucleophiles, yielding NCN' $^{\prime}$ ligands $\mathbf{2 b}$ and $\mathbf{2 c}$ in excellent yield (Scheme 5 ).

\section{NCN' palladacycle synthesis}

Ligands 2a-c were then selected for $\mathrm{C}-\mathrm{H}$ activation towards the palladacycle products. Refluxing the ligand in $\mathrm{AcOH}$ in the presence of $\mathrm{Pd}(\mathrm{OAc})_{2}$, followed by salt metathesis yielded the desired monomeric palladacycles 5a-c (Scheme 6).<smiles>OCc1cccc(O)c1</smiles><smiles>[Y]Cc1cccc(-c2ccccn2)c1</smiles>

i) $Y=O H(93 \%) 3$ ii) $Y=\operatorname{Br}(78 \%) 4$ iii) $\mathrm{Y}=\mathrm{NEt}_{2}(99 \%) \mathbf{2 b}$ or N-morpholinyl (>99\%) $2 \mathrm{c}$

Scheme 5 Synthesis of 4 and $\mathrm{NCN}^{\prime}$ ligands $2 \mathrm{~b}$ and $2 \mathrm{c}$ by nucleophilic displacement with amine nucleophiles. (i) 2-bromopyridine, $\mathrm{Pd}\left(\mathrm{PPh}_{3}\right)_{4}$, $\mathrm{K}_{3} \mathrm{PO}_{4}$, toluene/ $\mathrm{H}_{2} \mathrm{O} / \mathrm{EtOH}$. (ii) $\mathrm{HBr}$, (iii) $\mathrm{K}_{2} \mathrm{CO}_{3}, \mathrm{THF}$, amine.

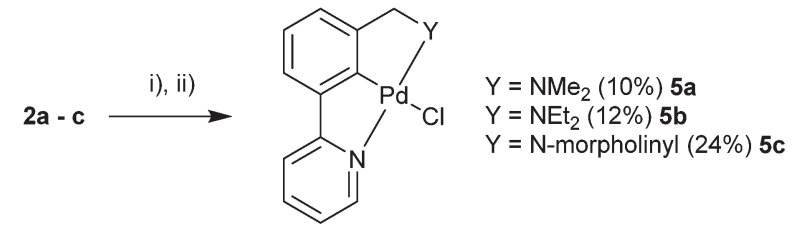

Scheme $6 \mathrm{C}-\mathrm{H}$ activation of unsymmetrical $\mathrm{NCN}^{\prime}$ ligands. (i) $\mathrm{Pd}(\mathrm{OAc})_{2}$, acetic acid. (ii) $\mathrm{LiCl}$ for $5 \mathrm{a}$ and $\mathrm{NaCl}$ for $5 \mathrm{~b}$ and $5 \mathrm{c}$, acetonitrile, $\mathrm{H}_{2} \mathrm{O}$.

Table 2 Optimisation of palladation of ligand $5 c$<smiles>[Z]C(C)(C)P1(=O)c2ccccc2CN1C</smiles>

$[\mathrm{Pd}(\mathrm{dmba})(\mu-\mathrm{Cl})]_{2}$

\begin{tabular}{lllc}
\hline Entry & Palladium source & Solvent & Yield (\%) \\
\hline $\mathbf{1}$ & $\mathbf{P d}(\mathrm{OAc})_{2}$ & AcOH & $\mathbf{2 4}$ \\
2 & $\mathrm{Pd}(\mathrm{OAc})_{2}$ & MeOH & 2 \\
3 & $\mathrm{Pd}(\mathrm{MeCN})_{4}\left(\mathrm{BF}_{4}\right)_{2}$ & MeCN & 12 \\
4 & {$[\mathrm{Pd}(\mathrm{dmba})(\mu-\mathrm{Cl})]_{2}$} & Toluene & -
\end{tabular}

The yields for forming these palladacycles are disappointing, due to significant formation of Pd black, and therefore an optimisation study for the synthesis of 5c was attempted (Table 2). Changing the solvent to $\mathrm{MeOH}$ (entry 2), the palladium source to in situ generated $\mathrm{Pd}(\mathrm{MeCN})_{4}\left(\mathrm{BF}_{4}\right)_{2}$ (entry 3), ${ }^{33}$ and a transcyclopalladation (entry 4$)^{34}$ using $\operatorname{Pd}_{2}(\mathrm{dmba})_{2} \mathrm{Cl}_{2}$ (Table 2) were attempted. It was found that indeed, the initial $\mathrm{Pd}(\mathrm{OAc})_{2}$ in $\mathrm{AcOH}$ method proved to be the most effective for palladation (entry 1).

However, literature yields for NCN pincers are often low, with several examples provided using $\mathrm{Pd}(\mathrm{OAc})_{2}$ as the palladium source (Table 3), showing the wide range of yields achieved for the key $\mathrm{C}-\mathrm{H}$ bond activation step from the corresponding NCN pincer ligands. Shaw's earlier work, in contrast, showed yields for PCP pincers of around $75 \% .^{2}$

In order to delve into such poor yields, we looked at the stability of $5 \mathrm{c}$ in refluxing $d_{4}$ acetic acid over time via ${ }^{1} \mathrm{H}$ NMR, which showed no degradation of the palladacycle over time, under the conditions used for $\mathrm{C}-\mathrm{H}$ activation. We also contemplated an oxidative addition of a $\operatorname{Pd}(0)$ salt to a bromide, ${ }^{38}$ although attempts to ortho-brominate $2 \mathrm{c}$ were unsuccessful.

\section{PCN palladacycle synthesis}

The synthetic route to unsymmetrical $\mathrm{NCN}^{\prime}$ pincer palladacycles has been modified to provide a route to unsymmetrical PCN pincer palladacycles. The synthesis of phosphinite palladacycles has been shown by Eberhard et al. ${ }^{39}$ from a benzyl alcohol using $\mathrm{ClPR}_{2}$, and therefore the benzyl alcohol 3 was used as the starting point for synthesis of a PCN pincer palladacycle. Due to the air sensitivity of the PCN ligand, after 
Table 3 Literature yields for palladation<smiles></smiles><smiles></smiles>

VI

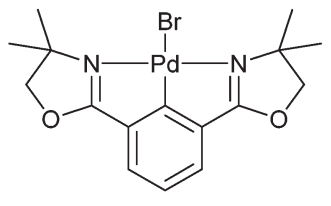

VII

\begin{tabular}{lll}
\hline Entry & Palladacycle & \multicolumn{1}{c}{ Yield/\% } \\
\hline 1 & $\mathrm{~V}^{35}$ & $17-70^{a}$ \\
2 & $\mathrm{VI}^{36}$ & $12-54^{a}$ \\
3 & $\mathrm{VII}^{37}$ & 3
\end{tabular}

${ }^{a}$ Depending on R group.

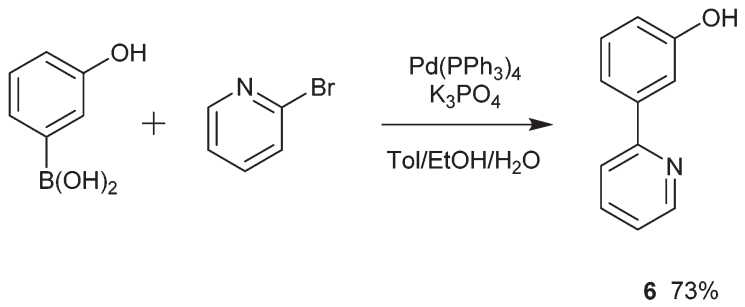

Scheme 7 Phenol-pyridine synthesis.

reaction with $\mathrm{ClPPh}_{2}, \mathrm{C}-\mathrm{H}$ bond activation using $\mathrm{Pd}(\mathrm{OAc})_{2}$ in $\mathrm{AcOH}$ was performed in situ (Scheme 8). This synthesis yields a mixed 5-,6-membered palladacycle, and for direct comparison with our 5-,5-membered $\mathrm{SCN}^{29}$ and $\mathrm{NCN}^{\prime}$ pincer palladacycles, a phenolic alcohol was synthesised (Scheme 7). Using the phenolic (6) and benzylic alcohols (3), the synthesis of PCN pincer palladacycles was undertaken (Scheme 8). The

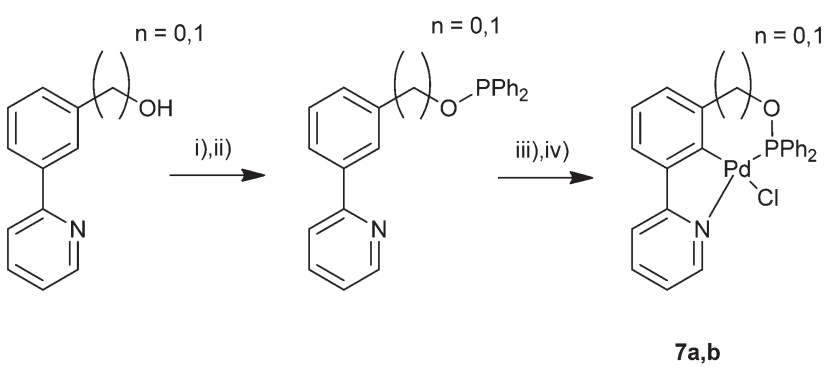

Scheme 8 Synthesis of PCN pincer palladacycles. (i) $\mathrm{NEt}_{3}, \mathrm{DMAP}, \mathrm{Et}_{2} \mathrm{O}$ $0{ }^{\circ} \mathrm{C}$. (ii) $\mathrm{ClPPh}_{2}$, rt. (iii) $\mathrm{Pd}(\mathrm{OAC})_{2}, \mathrm{AcOH}$. (iv) $\mathrm{NaCl}, \mathrm{H}_{2} \mathrm{O} / \mathrm{MeCN}$. 7a $n=1$, $7 \mathrm{~b} n=0$.

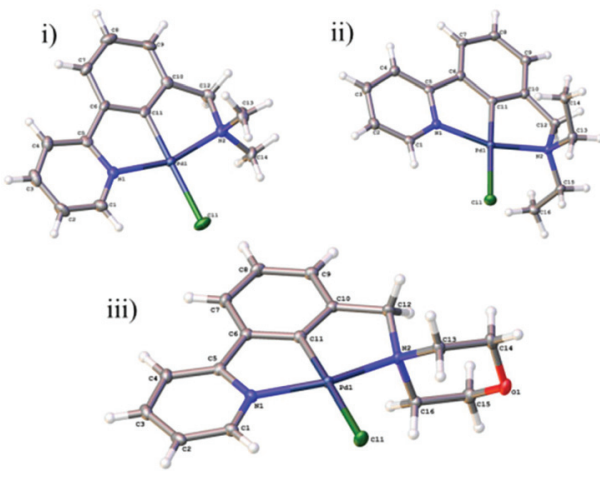

Fig. $4 \mathrm{NCN}^{\prime}$ pincer palladacycle crystal structures of (i) $5 \mathrm{a}$, (ii) $5 \mathrm{~b}$, (iii) 5c. Structures $5 \mathrm{a}$ and $5 \mathrm{~b}$ have 2 molecules in the asymmetric unit, with only one shown for clarity.

PCN pincer palladacycle structures were also confirmed using X-ray crystallography (Fig. 5).

Growth of crystals of $5 \mathbf{a}-\mathbf{c}$ and $7 \mathbf{a}$ and $7 \mathbf{b}$ by slow evaporation of $\mathrm{CH}_{2} \mathrm{Cl}_{2}$ from a saturated solution allowed their structures to be determined by X-ray diffraction (Fig. 4 and 5). All structures were as expected, with the metal in a distorted square planar arrangement.

Compound 5a crystallises in the monoclinic Pc space group with two independent molecules in the asymmetric unit. These are subject to $\pi-\pi$ interactions (benzene centroid-pyridine centroid distances: $3.564 \AA$ and $3.715 \AA$, offsets: $1.301 \AA$ and $1.386 \AA$ respectively). These pairs of molecules form layers with a 'herringbone' arrangement propagating along the crystallographic $b$ and $c$ axes.

The structure $\mathbf{5 b}$ crystallises in the monoclinic $P 2_{1} / c$ space group with two independent molecules in the asymmetric unit. The structure is formed from corrugated layers of molecules propagating along the crystallographic $a$ and $b$ axes with each alternate layer consisting of the same crystallographicallyindependent molecules.

The structure $5 \mathbf{c}$ crystallises in the monoclinic $P 2_{1} / n$ space group. The structure consists of $\pi-\pi$ stacks (benzene centroidpyridine centroid distances: $3.616 \AA$ and $3.705 \AA$, offsets: $1.319 \AA$ and $1.617 \AA$ respectively) along the crystallographic $c$ axis formed of alternating molecules related by inversion. There are weak $\mathrm{C}-\mathrm{H} \cdots \mathrm{O}(\mathrm{C} 2 \cdots \mathrm{O} 1=3.458(3) \AA$ and $\mathrm{C} 8 \cdots \mathrm{O} 1=$ 3.371 (3) Å) interactions between the stacks which lead to the formation of corrugated layers along the $a$ and $b$ axes.
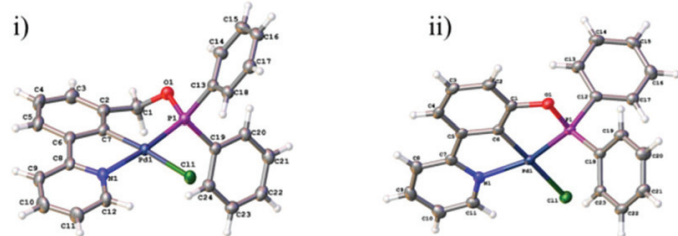

Fig. 5 PCN pincer palladacycle crystal structures of (i) $7 a$, and (ii) $7 b$. 
<smiles>C[SH]1Cc2cccc3c2B(Cl)N31</smiles>

8

Fig. 6 Previously published SCN pincer palladacycle by our group.

Structure 7a crystallises in the monoclinic $P 21 / n$ space group. The structure consists of columns of molecules closepacked along the crystallographic 21 screw axis parallel to the $b$ axis with $\pi-\pi$ interactions to neighbouring columns via the phenyl pyridine moieties (centroid-centroid distance: $3.894 \AA$, offset: $1.322 \AA$ ).

Structure $\mathbf{7 b}$ crystallises in the lower symmetry triclinic, $P \overline{1}$ space group. The structure is comprised of close-packed discrete layers parallel to the ac plane. These layers in turn are made up of close-packed 'chains' of C-H $\cdots \mathrm{O}(\mathrm{C} 19 \cdots \mathrm{O} 1=$ 3.405(2) §) dimers with $\pi-\pi$ interactions between neighbouring dimers via the phenyl pyridine moieties (centroid-centroid distance: 3.653 A , offset: $1.098 \AA$ ̊̊). Structures $5 \mathbf{a}-\mathbf{c}$ and $7 \mathbf{a}-\mathbf{b}$ were given CCDC numbers 1038592, 1038593, 1038594, 1476634 and 1476635 respectively.

\section{Catalytic investigation}

Next, $\mathbf{5 c}, \mathbf{7} \mathbf{a}$ and $\mathbf{7 b}$ were tested in the catalytic aldol condensation (Scheme 2) and compared with a previously published SCN pincer palladacycle (8) by our group (Fig. 6) ${ }^{29}$ along with commercially available $\mathrm{PdCl}_{2}(\mathrm{dtbpf})$ and $\mathrm{Pd}(\mathrm{OAc})_{2}$. The results are presented in Table 4, alongside the published data by Szabó and co-workers for symmetrical PCP and SCS pincer palladacycles, as well an unsymmetrical PCS pincer palladacycle (Scheme 2). ${ }^{27}$

Table 4 Aldol condensation results obtained using pincer palladacycles, and commercially available palladium catalysts

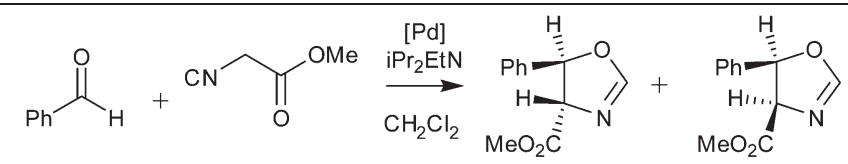

\begin{tabular}{llll}
\hline Entry & Catalyst & ${\text { trans } / \text { cis } \text { ratio }^{a} / \%}$ & Yield $/ \%$ \\
\hline 1 & $\mathbf{7 a}$ & $85 / 15$ & 99 \\
$2^{27}$ & PCP $^{b}$ & $82 / 18$ & \\
3 & $\mathbf{7 b}$ & $73 / 27$ & Quantitative \\
$4^{27}$ & $\mathrm{SCS}^{b}$ & $59 / 41$ & \\
5 & $\mathbf{5 c}$ & $59 / 41$ & 93 \\
6 & $\mathrm{Pd}(\mathrm{OAc})_{2}$ & $58 / 42$ & Quantitative \\
7 & $\mathbf{8}$ & $57 / 43$ & 99 \\
$8^{27}$ & $\mathrm{PCS}^{b}$ & $57 / 43$ & Quantitative \\
9 & $\mathrm{PdCl}_{2}(\mathrm{dtbpf})$ & $56 / 44$ &
\end{tabular}

${ }^{a}$ Performed in duplicate, average of 2 runs. trans/cis ratio determined by crude ${ }^{1} \mathrm{H}$ NMR of the resulting mixture. Reaction conditions: methylisocyanoacetate ( 1 eq.), benzaldehyde ( 1 eq.), ${ }^{\mathrm{i}} \operatorname{Pr}_{2} \operatorname{EtN}(0.1$ eq.), $[\mathrm{Pd}](1 \mathrm{~mol} \%), \operatorname{DCM}\left(5 \mathrm{~cm}^{3}\right), 24 \mathrm{~h}, \mathrm{rt}^{b}$ Scheme 2.

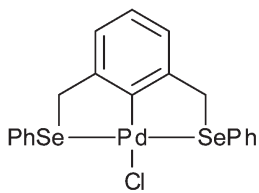

Fig. 7 Symmetrical SeCSe pincer palladacycle.

Table 5 Vinyl epoxide coupling to phenylboronic acid using pincer palladacycles

\begin{tabular}{|c|c|c|c|c|}
\hline & $+\mathrm{PhB}(\mathrm{C}$ & $\begin{array}{l}{[\mathrm{Pd}] 4 \mathrm{~mol} \%} \\
\stackrel{\mathrm{Cs}}{\mathrm{Cs}_{2} \mathrm{CO}_{3}} \\
\mathrm{THF} / \mathrm{H}_{2} \mathrm{O}\end{array}$ & $\overbrace{\mathrm{Ph}}+$ & Branched \\
\hline Entry & Catalyst & Linear $^{a} / \%$ & Branched $^{a} / \%$ & Yield/\% \\
\hline $1^{28}$ & SeCSe & 92 & 8 & 94 \\
\hline 2 & SCS & 78 & 22 & $>99$ \\
\hline 3 & $7 a$ & 66 & 34 & 66 \\
\hline 4 & $7 \mathbf{b}$ & 64 & 36 & 96 \\
\hline 5 & 8 & 64 & 36 & 96 \\
\hline 6 & $5 c$ & 60 & 40 & 84 \\
\hline
\end{tabular}

${ }^{a}$ Performed in duplicate, average of two runs. Linear/branched ratio determined by crude ${ }^{1} \mathrm{H}$ NMR of the resulting mixture. Reaction conditions: 2-vinyl oxirane (1 eq.), $\mathrm{PhB}(\mathrm{OH})_{2}$ (1.2 eq.), $\mathrm{Cs}_{2} \mathrm{CO}_{3}$ (2 eq.), [Pd] (4 mol\%), 10:1 THF : $\mathrm{H}_{2} \mathrm{O}\left(3 \mathrm{~cm}^{3}\right), 24 \mathrm{~h} \mathrm{rt}$.

The results presented in Table 4 show that the family of palladacycles synthesised by our group, with $\mathrm{SCN}, \mathrm{NCN}^{\prime}$ and PCN examples, provides the opportunity to fine tune catalytic activity, with the choice of donor group influencing the stereochemical outcomes of the aldol condensation. The novel PCN pincer palladacycle 7a provides the highest trans selectivity of all catalysts tested, and slightly more than the literature PCP example, whereas the $\mathrm{SCN}$ and $\mathrm{NCN}^{\prime}$ provide a greater proportion of the cis $^{\text {product. }}{ }^{27}$

In addition, catalysis of the coupling of a vinylepoxide and phenylboronic acid was tested, using the $\mathrm{NCN}^{\prime}$, SCN and PCN pincer palladacycles, and compared to literature SeCSe results shown in Fig. $7,{ }^{28}$ and our new results using the symmetrical SCS palladacycle (Scheme 2). The coupling and results are presented in Table 5.

The results presented in Table 5 show that the symmetrical pincer palladacycles, SeCSe and SCS achieve the greatest linear selectivity $(>78 \%)$, whereas the unsymmetrical pincer palladacycles achieve a higher proportion of the branched product (>34\%). Clearly the presence of unsymmetrical pincer palladacycles is having an effect of the stereochemical outcome of the reaction, increasing the proportion of the branched product.

\section{Conclusions}

The simple synthesis of three $\mathrm{NCN}^{\prime}$ ligands has been shown. Their $\mathrm{C}-\mathrm{H}$ activation yielded three new $\mathrm{NCN}^{\prime}$ pincer palladacycles. Similarly, two novel PCN pincer palladacycles were syn- 
thesised, with 5-,5-, and 5-,6-membered rings and all palladacycles were characterised by X-ray crystallography.

The catalytic applications of the $\mathrm{NCN}^{\prime}, \mathrm{SCN}$ and $\mathrm{PCN}$ pincer palladacycles, along with several other examples were considered in two Pd(II)-mediated reactions, an aldol condensation and vinyl epoxide coupling. It was found that in the aldol condensation, the ability to fine tune the stereochemical outcome of the reaction is possible, by varying the donor atoms in the palladacycle catalyst. It was also shown in the vinyl epoxide coupling that the unsymmetrical pincer palladacycles achieve different product ratios than the symmetrical palladacycles tested, demonstrating the potential benefits of unsymmetrical palladacycles in catalytic applications.

Further work is being undertaken towards varying the families of unsymmetrical palladacycles, supported by DFT investigations into their bonding properties and reactivity. Moreover, it is hoped that such simple synthetic routes to unsymmetrical pincer ligands may encourage others to employ these in other areas of transition metal chemistry and catalysis.

\section{Experimental}

\section{General details}

Solvents and chemicals were purchased from commercial suppliers and used without further purification, with reactions taking place open to atmosphere and moisture.

\section{Instrumentation}

${ }^{1} \mathrm{H}$ and ${ }^{13} \mathrm{C}$ spectra were recorded on either a Varian 400 or $500 \mathrm{MHz}$ spectrometer. HRMS were obtained on an ESI mass spectrometer using a Bruker Daltonics Apex III, with source Apollo ESI, using methanol as the spray. Flash chromatography was performed on an automated ISCO RF75. GC measurements were obtained using a Perkin Elmer Autosystem XL Gas Chromatograph, utilizing a flame ionization detector, and a Supelco MDN-5S $30 \mathrm{~m} \times 0.25 \mathrm{~mm} \times 0.25 \mu \mathrm{m}$ column, with a He mobile phase. Elemental analyses were run by the London Metropolitan University Elemental Analysis Service. Crystal structures were obtained by the UK National Crystallography Service at the University of Southampton. ${ }^{40}$

3-(Pyridin-2-yl)benzaldehyde (1). (3-Formylphenyl)boronic acid (4.24 mmol, $635 \mathrm{mg})$, 2-bromopyridine (4.24 $\mathrm{mmol}$, $\left.0.412 \mathrm{~cm}^{3}\right), \operatorname{Pd}(\mathrm{dppf}) \mathrm{Cl}_{2}(0.17 \mathrm{mmol}, 122 \mathrm{mg}), 1 \mathrm{M} \mathrm{Na} \mathrm{CO}_{3}$ $\left(5 \mathrm{~cm}^{3}\right)$, toluene $\left(10 \mathrm{~cm}^{3}\right)$ and EtOH $\left(5 \mathrm{~cm}^{3}\right)$ were added to a sealed microwave vial and irradiated (maximum power $300 \mathrm{~W}$, dynamic heating) for 20 minutes at $150{ }^{\circ} \mathrm{C}$. The reaction mixture was filtered over celite, the solvent was then removed in vacuo. The crude mixture was dissolved in $\mathrm{H}_{2} \mathrm{O}\left(25 \mathrm{~cm}^{3}\right)$ and ethyl acetate $\left(25 \mathrm{~cm}^{3}\right)$, extracted with ethyl acetate $\left(2 \times 25 \mathrm{~cm}^{3}\right)$, washed with $\mathrm{H}_{2} \mathrm{O}\left(2 \times 25 \mathrm{~cm}^{3}\right)$ and brine $\left(25 \mathrm{~cm}^{3}\right)$. The organic layers were dried over anhydrous $\mathrm{MgSO}_{4}$, filtered, and the solvent was removed in vacuo. The crude product was purified using flash column chromatography $\left(7: 3 \quad \mathrm{CH}_{2} \mathrm{Cl}_{2}\right.$ : ethyl acetate) yielding $402 \mathrm{mg}$ of the expected product 1 as a yellow oil in $74 \%$ yield. ${ }^{1} \mathrm{H}$ NMR (500 MHz, chloroform- $d$ ) $\delta 10.13$ (s,
$1 \mathrm{H}), 8.74(\mathrm{~d}, J=4.8 \mathrm{~Hz}, 1 \mathrm{H}), 8.52(\mathrm{~s}, 1 \mathrm{H}), 8.30(\mathrm{~d}, J=7.7 \mathrm{~Hz}$, $1 \mathrm{H}), 7.94(\mathrm{~d}, J=7.7 \mathrm{~Hz}, 1 \mathrm{H}), 7.82-7.79(\mathrm{~m}, 2 \mathrm{H}), 7.65$ (dd, $J=$ 7.7, $7.7 \mathrm{~Hz}, 1 \mathrm{H}), 7.32-7.28(\mathrm{~m}, 1 \mathrm{H}) .{ }^{13} \mathrm{C}$ NMR (126 MHz, chloroform- $d$ ) $\delta 192.2$, 155.9, 149.9, 140.3, 137.0, 136.9, 132.7, 129.7, 129.5, 128.4, 122.8, 120.6. HRMS. Calcd for $\left[\mathrm{C}_{12} \mathrm{H}_{9} \mathrm{NO}+\mathrm{H}\right]^{+}$ 184.0757. Found 184.0761.

$N, N$-Dimethyl-1-(3-(pyridin-2-yl)phenyl)methanamine (2a). 3-(Pyridin-2-yl)benzaldehyde (1) (5.76 mmol, $1.06 \mathrm{~g}$ ), $\mathrm{HNMe}_{2} \cdot \mathrm{HCl}(12.1 \mathrm{mmol}, 987 \mathrm{mg}), \mathrm{Ti}(\mathrm{OiPr})_{4}(11.6 \mathrm{mmol}$, $3.30 \mathrm{~g})$ and EtOH $\left(50 \mathrm{~cm}^{3}\right)$ were added to a round bottom flask and stirred at rt overnight. $\mathrm{NaBH}_{4}(8.63 \mathrm{mmol}, 327 \mathrm{mg})$ was then added to the flask and the mixture was stirred at rt for 24 hours. The reaction mixture was quenched using aqueous ammonia ( $35 \%$ in $\left.\mathrm{H}_{2} \mathrm{O}, 30 \mathrm{~cm}^{3}\right)$ and filtered. The solid residue was washed with $\mathrm{CH}_{2} \mathrm{Cl}_{2}\left(50 \mathrm{~cm}^{3}\right)$ and the product was extracted from the filtrate using $\mathrm{CH}_{2} \mathrm{Cl}_{2}\left(3 \times 35 \mathrm{~cm}^{3}\right)$. The organic layers were dried over anhydrous $\mathrm{MgSO}_{4}$ and the solvent was removed in vacuo yielding $0.99 \mathrm{~g}$ of the expected product $2 \mathrm{a}$ as a green oil in $81 \%$ yield. ${ }^{1} \mathrm{H}$ NMR $(400 \mathrm{MHz}$, chloroform-d) $\delta 8.62(\mathrm{~d}, J=3.8 \mathrm{~Hz}, 1 \mathrm{H}), 7.91(\mathrm{~s}, 1 \mathrm{H}), 7.84(\mathrm{~d}$, $J=7.5 \mathrm{~Hz}, 1 \mathrm{H}), 7.67-7.60$ (m, 2H), 7.38-7.31 (m, 2H), 7.12-7.10 (m, 1H), 3.45 (s, 2H), 2.20 (s, 6H). ${ }^{13} \mathrm{C}$ NMR (126 MHz, chloroform-d) $\delta 157.4,149.5,139.4,136.6,129.7,128.6,127.6,125.7$, 122.0, 120.6, 64.3, 45.3 (2C). 1 carbon missing. HRMS. Calcd for $\left[\mathrm{C}_{14} \mathrm{H}_{16} \mathrm{~N}_{2}+\mathrm{H}\right]^{+}$213.1386. Found 213.1384.

$N, N$-Diethyl-1-(3-(pyridin-2-yl)phenyl)methanamine (2b). 2-(3-(Bromomethyl)phenyl)pyridine (3) (2.78 mmol, $690 \mathrm{mg}$ ), diethylamine $\left(4.17 \mathrm{mmol}, 0.43 \mathrm{~cm}^{3}\right), \mathrm{K}_{2} \mathrm{CO}_{3}(12.1 \mathrm{mmol}$, $1.67 \mathrm{~g})$ and THF $\left(8 \mathrm{~cm}^{3}\right)$ were added to a microwave vial and then stirred under microwave irradiation (maximum power $300 \mathrm{~W}$, dynamic heating) at $150{ }^{\circ} \mathrm{C}$ for 30 minutes. The cooled reaction mixture was added to $\mathrm{H}_{2} \mathrm{O}\left(25 \mathrm{~cm}^{3}\right)$ and the crude product was extracted using ethyl acetate $\left(3 \times 25 \mathrm{~cm}^{3}\right)$, washed with $\mathrm{H}_{2} \mathrm{O}\left(2 \times 25 \mathrm{~cm}^{3}\right)$ and brine $\left(25 \mathrm{~cm}^{3}\right)$. The combined organic layers were dried over anhydrous $\mathrm{Na}_{2} \mathrm{SO}_{4}$, filtered and solvent removed in vacuo yielding $665 \mathrm{mg}$ of the expected product $\mathbf{2 b}$ as a yellow oil in $99 \%$ yield. ${ }^{1} \mathrm{H}$ NMR $(500 \mathrm{MHz}$, chloroform- $d$ ) $\delta 8.69$ (d, $J=4.8 \mathrm{~Hz}, 1 \mathrm{H}), 7.94$ (s, 1H), 7.86 (ddd, $J=5.3,5.3,1.9 \mathrm{~Hz}, 1 \mathrm{H}), 7.75-7.74(\mathrm{~m}, 2 \mathrm{H}), 7.43-7.41(\mathrm{~m}, 2 \mathrm{H})$, $7.24-7.20(\mathrm{~m}, 1 \mathrm{H}), 3.66(\mathrm{~s}, 2 \mathrm{H}), 2.56(\mathrm{q}, J=7.1 \mathrm{~Hz}, 4 \mathrm{H}), 1.06$ $(\mathrm{t}, J=7.1 \mathrm{~Hz}, 6 \mathrm{H}) .{ }^{13} \mathrm{C}$ NMR (100 MHz, chloroform- $d$ ) $\delta 157.7$, 149.6 , 140.7, 139.3, 136.6, 129.5, 128.5, 127.4, 125.3, 121.9, 120.6, 57.6, 46.8 (2C), 11.8 (2C). HRMS. Calcd for $\left[\mathrm{C}_{16} \mathrm{H}_{20} \mathrm{~N}_{2}+\mathrm{H}\right]^{+}$241.1699. Found 241.1692.

4-(3-(Pyridin-2-yl)benzyl)morpholine (2c). Same method used as 2a. $638 \mathrm{mg}$ of the expected product 2c was obtained as a yellow oil in quantitative yield. ${ }^{1} \mathrm{H}$ NMR $(500 \mathrm{MHz}$, chloroform- $d$ ) $\delta 8.70(\mathrm{~d}, J=4.9 \mathrm{~Hz}, 1 \mathrm{H}), 7.96(\mathrm{~s}, 1 \mathrm{H}), 7.87$ (ddd, $J=$ 7.2, 1.7, 1.7 Hz, 1H), 7.77-7.73 (m, 2H), 7.45-7.40 (m, 2H), 7.23 (ddd, $J=7.4,4.9,2.4 \mathrm{~Hz}, 1 \mathrm{H}), 3.72(\mathrm{t}, J=4.6 \mathrm{~Hz}, 4 \mathrm{H}), 3.59$ (s, 2H), 2.48 (t, $J=4.6 \mathrm{~Hz}, 4 \mathrm{H}) .{ }^{13} \mathrm{C}$ NMR (100 MHz, chloroform-d) $\delta 157.5,149.7,139.5,138.2,136.8,129.9,128.8,127.9,126.0$, 122.2, 120.8, 67.0 (2C), 63.5, 53.7 (2C). HRMS. Calcd for $\left[\mathrm{C}_{16} \mathrm{H}_{18} \mathrm{~N}_{2} \mathrm{O}+\mathrm{H}\right]^{+}$255.1492. Found 255.1484.

Palladacycle (5a). N,N-Dimethyl-1-(3-(pyridin-2-yl)phenyl) methanamine (2a) $(0.80 \mathrm{mmol}, 170 \mathrm{mg})$ and $\mathrm{Pd}(\mathrm{OAc})_{2}$ 
(0.83 mmol, $186 \mathrm{mg}$ ) were dissolved in $\mathrm{AcOH}\left(15 \mathrm{~cm}^{3}\right)$ and stirred at reflux $\left(125^{\circ} \mathrm{C}\right)$ for 3 hours. The solvent was removed in vacuo, and reconcentrated with $\mathrm{CH}_{2} \mathrm{Cl}_{2}\left(5 \times 50 \mathrm{~cm}^{3}\right)$ to remove any residual acetic acid. The crude mixture was dissolved in $\mathrm{MeOH}\left(10 \mathrm{~cm}^{3}\right)$ and $\mathrm{LiCl}$ (excess) was added. The mixture was stirred at $\mathrm{rt}$ for $30 \mathrm{~min}$. The solvent was removed in vacuo, and the crude mixture dissolved in $\mathrm{CH}_{2} \mathrm{Cl}_{2}\left(25 \mathrm{~cm}^{3}\right)$ and $\mathrm{H}_{2} \mathrm{O}\left(25 \mathrm{~cm}^{3}\right)$. The crude product was extracted using $\mathrm{CH}_{2} \mathrm{Cl}_{2}\left(2 \times 25 \mathrm{~cm}^{3}\right)$, washed with $\mathrm{H}_{2} \mathrm{O}\left(3 \times 25 \mathrm{~cm}^{3}\right)$. The combined organic layers were dried over $\mathrm{MgSO}_{4}$, filtered and the solvent removed in vacuo. The crude product was purified by recystallisation from $\mathrm{CH}_{2} \mathrm{Cl}_{2} /$ hexane yielding $82 \mathrm{mg}$ of the expected product $5 \mathbf{a}$ as a yellow solid in $10 \%$ yield. ${ }^{1} \mathrm{H}$ NMR (500 MHz, chloroform- $d$ ) $\delta 9.02$ (ddd, $J=5.6,1.6,0.7 \mathrm{~Hz}, 1 \mathrm{H}$ ), 7.81 (ddd, $J=7.8,7.8,1.7 \mathrm{~Hz}, 1 \mathrm{H}), 7.58$ (d, $J=7.8 \mathrm{~Hz}, 1 \mathrm{H}$ ), $7.27-7.25$ (m, 1H), 7.17 (ddd, $J=7.6,5.6,1.4 \mathrm{~Hz}, 1 \mathrm{H}), 7.09$ (dd, $J=7.6,7.6 \mathrm{~Hz}, 1 \mathrm{H}), 6.92(\mathrm{~d}, J=7.6 \mathrm{~Hz}, 1 \mathrm{H}), 4.13(\mathrm{~s}, 2 \mathrm{H}), 3.08$ (s, 6H). ${ }^{13} \mathrm{C}$ NMR (126 MHz, chloroform-d) $\delta$ 165.1, 164.6, $152.4,145.9$, 142.4, 138.6, 124.5, 123.4, 122.7, 121.1, 118.6, 74.9, 53.1 (2C). HRMS. Calcd for $\left[\mathrm{C}_{14} \mathrm{H}_{15} \mathrm{~N}_{2} \mathrm{Pd}\right]^{+} 317.0259$. Found 317.0269. Anal. Calcd for $\mathrm{C}_{14} \mathrm{H}_{15} \mathrm{~N}_{2} \mathrm{PdCl}$ : C, 47.61; $\mathrm{H}$, 4.28; N, 7.93. Found: C, 47.54; H. 4.34; N, 7.84.

Palladacycle (5b). $N, N$-Diethyl-1-(3-(pyridin-2-yl)phenyl)ethanamine (2b) $(1.25 \mathrm{mmol}, 301 \mathrm{mg})$ and $\mathrm{Pd}(\mathrm{OAc})_{2}(1.26 \mathrm{mmol}$, $310 \mathrm{mg}$ ) were dissolved in $\mathrm{AcOH}\left(4 \mathrm{~cm}^{3}\right)$ and stirred at reflux $\left(125^{\circ} \mathrm{C}\right)$ for 4 hours. The solvent was removed in vacuo, and reconcentrated with $\mathrm{CH}_{2} \mathrm{Cl}_{2}\left(5 \times 50 \mathrm{~cm}^{3}\right)$ to remove any residual acetic acid. The crude mixture was dissolved in MeCN $\left(10 \mathrm{~cm}^{3}\right)$ and $\mathrm{H}_{2} \mathrm{O}\left(10 \mathrm{~cm}^{3}\right)$ and $\mathrm{NaCl}(13.0 \mathrm{mmol}, 761 \mathrm{mg})$ was added. The mixture was stirred at rt for 3 hours. The solvent was removed in vacuo, and the crude mixture dissolved in $\mathrm{CH}_{2} \mathrm{Cl}_{2}\left(35 \mathrm{~cm}^{3}\right)$ and $\mathrm{H}_{2} \mathrm{O}\left(35 \mathrm{~cm}^{3}\right)$. The crude product was extracted using $\mathrm{CH}_{2} \mathrm{Cl}_{2}\left(2 \times 35 \mathrm{~cm}^{3}\right)$, washed with $\mathrm{H}_{2} \mathrm{O}(2 \times$ $\left.25 \mathrm{~cm}^{3}\right)$ and brine $\left(25 \mathrm{~cm}^{3}\right)$. The organic layers were dried over $\mathrm{MgSO}_{4}$, filtered and the solvent removed in vacuo. The crude product was purified by flash column chromatography $(9: 1$ $\mathrm{CH}_{2} \mathrm{Cl}_{2}$ : ethyl acetate) yielding $59 \mathrm{mg}$ of the expected product 5b as a yellow solid in $12 \%$ yield. ${ }^{1} \mathrm{H}$ NMR $(500 \mathrm{MHz}$, chloroform- $d$ ) $\delta 9.06(\mathrm{~d}, J=5.5 \mathrm{~Hz}, 1 \mathrm{H}), 7.80(\mathrm{ddd}, J=7.8,7.8,1.6 \mathrm{~Hz}$, $1 \mathrm{H}), 7.57$ (d, $J=7.8 \mathrm{~Hz}, 1 \mathrm{H}), 7.23$ (d, $J=7.8 \mathrm{~Hz}, 1 \mathrm{H}), 7.17$ (ddd, $J=7.6,5.5,1.3 \mathrm{~Hz}, 1 \mathrm{H}), 7.06(\mathrm{dd}, J=7.6,7.6 \mathrm{~Hz}, 1 \mathrm{H}), 6.89$ (d, $J=7.6 \mathrm{~Hz}, 1 \mathrm{H}), 4.16(\mathrm{~s}, 2 \mathrm{H}), 3.51-3.44(\mathrm{~m}, 2 \mathrm{H}), 2.85-2.78(\mathrm{~m}$, $2 \mathrm{H}), 1.61(\mathrm{t}, J=7.1 \mathrm{~Hz}, 6 \mathrm{H}) .{ }^{13} \mathrm{C}$ NMR $(100 \mathrm{MHz}$, chloroform- $d$ ) $\delta 165.0,163.4,152.2,148.1,142.4,138.5,124.2,122.7,122.4$, 120.8, 118.4, 67.2, 58.1 (2C), 14.1 (2C). HRMS. Calcd for $\left[\mathrm{C}_{16} \mathrm{H}_{19} \mathrm{~N}_{2} \mathrm{Pd}\right]^{+}$345.0578. Found 345.0564. Anal. Calcd for $\mathrm{C}_{16} \mathrm{H}_{19} \mathrm{~N}_{2} \mathrm{PdCl}$ : C, 50.41; H, 5.02; N, 7.35. Found: C, 50.34; H, 4.92; N, 7.46.

Palladacycle (5c). Same method as $\mathbf{5 b}$. The crude product was purified by flash column chromatography $\left(7: 3 \mathrm{CH}_{2} \mathrm{Cl}_{2}\right.$ : ethyl acetate) yielding $103 \mathrm{mg}$ of the expected product $5 \mathrm{c}$ as a yellow solid in $24 \%$ yield. ${ }^{1} \mathrm{H}$ NMR (500 MHz, chloroform- $d$ ) $\delta$ $9.16(\mathrm{~d}, J=5.6 \mathrm{~Hz}, 1 \mathrm{H}), 7.80(\mathrm{dd}, J=7.8,7.8 \mathrm{~Hz}, 1 \mathrm{H}), 7.56$ (d, $J=7.8 \mathrm{~Hz}, 1 \mathrm{H}), 7.23(\mathrm{~d}, J=7.8 \mathrm{~Hz}, 1 \mathrm{H}), 7.17(\mathrm{dd}, J=7.6,5.6$ $\mathrm{Hz}, 1 \mathrm{H}), 7.09$ (dd, $J=7.6,7.6 \mathrm{~Hz}, 1 \mathrm{H}), 6.96$ (d, $J=7.6 \mathrm{~Hz}, 1 \mathrm{H})$, $4.38(\mathrm{~s}, 2 \mathrm{H}), 4.30-4.28(\mathrm{~m}, 2 \mathrm{H}), 4.10-4.06(\mathrm{~m}, 2 \mathrm{H}), 3.90-3.86$ (m, 2H), 3.01-2.97 (m, 2H). ${ }^{13} \mathrm{C}$ NMR (100 MHz, chloroform- $d$ ) $\delta$ 165.1, 163.6, 152.4, 144.5, 142.4, 138.7, 124.8, 123.6, 122.6, 121.2, 118.5, 69.9, 62.8 (2C), 59.64 (2C). HRMS. Calcd for $\left[\mathrm{C}_{16} \mathrm{H}_{17} \mathrm{~N}_{2} \mathrm{OPd}\right]^{+}$359.0370. Found 359.0359. Anal. Calcd for $\mathrm{C}_{16} \mathrm{H}_{17} \mathrm{~N}_{2} \mathrm{OPdCl}$ : C, 48.63; H, 4.34; N, 7.09. Found: C, 48.59; H, 4.42; N, 6.97.

3-(Pyridin-2-yl)phenol (6). 3-[Hydroxyphenyl]boronic acid (3.59 mmol, $496 \mathrm{mg})$, 2-bromopyridine (3.59 $\mathrm{mmol}$, $\left.0.342 \mathrm{~cm}^{3}\right), \quad \mathrm{Pd}\left(\mathrm{PPh}_{3}\right)_{4} \quad(0.14 \mathrm{mmol}, 164 \mathrm{mg}), \quad \mathrm{K}_{3} \mathrm{PO}_{4}$ (7.16 mmol, $1.52 \mathrm{~g}), \mathrm{H}_{2} \mathrm{O}\left(10 \mathrm{~cm}^{3}\right)$, toluene $\left(7.5 \mathrm{~cm}^{3}\right)$ and $\mathrm{EtOH}$ $\left(5 \mathrm{~cm}^{3}\right)$ were added to a sealed $35 \mathrm{~cm}^{3}$ microwave vial and stirred under microwave irradiation (maximum power $300 \mathrm{~W}$, dynamic heating) at $150{ }^{\circ} \mathrm{C}$ for $20 \mathrm{~min}$. The reaction was cooled, and the solvent removed in vacuo. The mixture was diluted with $\mathrm{H}_{2} \mathrm{O}\left(25 \mathrm{~cm}^{3}\right)$ and $\mathrm{Et}_{2} \mathrm{O}\left(25 \mathrm{~cm}^{3}\right)$, washed with $\mathrm{H}_{2} \mathrm{O}\left(2 \times 25 \mathrm{~cm}^{3}\right)$ and brine $\left(25 \mathrm{~cm}^{3}\right)$. The combined organic layers were dried over anhydrous $\mathrm{MgSO}_{4}$, filtered, and concentrated in vacuo. The crude material was purified using flash column chromatography ( $8: 2 \mathrm{CH}_{2} \mathrm{Cl}_{2}$ : EtOAC) yielding $250 \mathrm{mg}$ of the expected product 6 as a clear liquid in $73 \%$ yield. ${ }^{1} \mathrm{H}$ NMR (500 MHz, chloroform- $d$ ) $\delta(\mathrm{ppm}): 9.51$ (d, 1H), 8.63 (d, $J=4.4 \mathrm{~Hz}, 1 \mathrm{H}), 7.86-7.83(\mathrm{~m}, 2 \mathrm{H}), 7.51(\mathrm{~s}, 1 \mathrm{H}), 7.47(\mathrm{~d}, J=7.9$ $\mathrm{Hz}, 1 \mathrm{H}), 7.34-7.32$ (m, 1H), 7.24 (dd, $J=7.9,7.9 \mathrm{~Hz}, 1 \mathrm{H}), 6.83$ $(\mathrm{d}, J=7.9 \mathrm{~Hz}, 1 \mathrm{H}) .{ }^{13} \mathrm{C}$ NMR $(126 \mathrm{MHz}$, chloroform- $d) \delta(\mathrm{ppm})$ : 158.2 , 156.5, 149.9, 140.5, 137.6, 130.2, 123.0, 120.6, 117.7, 116.5, 113.8. HRMS. Calcd for $\left[\mathrm{C}_{11} \mathrm{H}_{9} \mathrm{NO}+\mathrm{H}\right]^{+} 172.0757$. Found 172.0755.

Palladacycle (7a). Under an argon atmosphere 3-(pyridin-2yl)phenyl]methanol (418 mg, $2.26 \mathrm{mmol}), \mathrm{NEt}_{3}\left(0.63 \mathrm{~cm}^{3}\right.$, $4.52 \mathrm{mmol}$ ), and DMAP (spatula tip) were dissolved in $\mathrm{Et}_{2} \mathrm{O}$ $\left(5 \mathrm{~cm}^{3}\right)$ and cooled to $0{ }^{\circ} \mathrm{C}$. $\mathrm{ClPPh}_{2}\left(0.41 \mathrm{~cm}^{3}, 2.22 \mathrm{mmol}\right)$ was added dropwise to the solution forming a white precipitate. The reaction was warmed to room temperature and stirred for $3 \mathrm{~h}$. The crude mixture was filtered under an argon atmosphere and the solvent removed in vacuo. $\mathrm{Pd}(\mathrm{OAc})_{2}(687 \mathrm{mg}$, $3.06 \mathrm{mmol}$ ) was added to the crude intermediate, dissolved in $\mathrm{AcOH}\left(5 \mathrm{~cm}^{3}\right)$, and heated at reflux $\mathrm{o} / \mathrm{n}$. The solvent was removed in vacuo and reconcentrated with $\mathrm{CH}_{2} \mathrm{Cl}_{2}$ to remove residual $\mathrm{AcOH}$. $\mathrm{NaCl}(1.16 \mathrm{~g}, 19.9 \mathrm{mmol})$ was added to the crude mixture, which was then dissolved in $\operatorname{MeCN}\left(10 \mathrm{~cm}^{3}\right)$ and $\mathrm{H}_{2} \mathrm{O}\left(10 \mathrm{~cm}^{3}\right)$, and stirred at room temperature $\mathrm{o} / \mathrm{n}$. The solvent was removed in vacuo, and the crude mixture dissolved in $\mathrm{CH}_{2} \mathrm{Cl}_{2}$ and separated using a hydrophobic frit. The crude product was purified using flash column chromatography $(7: 3$ $\mathrm{CH}_{2} \mathrm{Cl}_{2}$ : EtOAc) yielding $383 \mathrm{mg}$ of the expected product (7a) as a yellow solid in $29 \%$ yield. ${ }^{1} \mathrm{H}$ NMR $(500 \mathrm{MHz}$, chloroformd) $\delta(\mathrm{ppm}): 9.38(\mathrm{~s}, 1 \mathrm{H}), 8.08-8.03(\mathrm{~m}, 4 \mathrm{H}), 7.88-7.79(\mathrm{~m}, 2 \mathrm{H})$, $7.63(\mathrm{~d}, J=7.6 \mathrm{~Hz}, 1 \mathrm{H}), 7.52-7.44(\mathrm{~m}, 6 \mathrm{H}), 7.30(\mathrm{~d}, J=6.6 \mathrm{~Hz}$, $1 \mathrm{H}), 7.19$ (dd, $J=7.6,7.6 \mathrm{~Hz}, 1 \mathrm{H}), 7.03(\mathrm{~d}, J=6.6 \mathrm{~Hz}, 1 \mathrm{H}), 4.83$ (d, $J=19.6 \mathrm{~Hz}, 2 \mathrm{H}) .{ }^{13} \mathrm{C}$ NMR $(126 \mathrm{MHz}$, chloroform- $d$ ) $\delta$ (ppm): 163.3, 151.9, 149.4, 148.2, 139.2 (2C), 136.5, 133.2 (d, $\left.{ }^{2} J_{P C}=13.4 \mathrm{~Hz}\right), 133.0\left(\mathrm{~d},{ }^{1} J_{P C}=59.8 \mathrm{~Hz}, 2 \mathrm{C}\right), 131.7\left(\mathrm{~d},{ }^{3} J_{P C}=2.4\right.$ $\mathrm{Hz}), 128.4\left(\mathrm{~d},{ }^{3} J_{P C}=2.0 \mathrm{~Hz}, 4 \mathrm{C}\right), 128.3\left(\mathrm{~d},{ }^{2} J_{P C}=11.6 \mathrm{~Hz}, 4 \mathrm{C}\right)$, 125.4, 124.1, 122.5 (d, $\left.{ }^{3} J_{P C}=3.4 \mathrm{~Hz}\right), 118.5\left(\mathrm{~d},{ }^{3} J_{P C}=1.9 \mathrm{~Hz}\right)$, $72.1\left(\mathrm{~d},{ }^{2} J_{P C}=2.8 \mathrm{~Hz}\right) .{ }^{31} \mathrm{P}$ NMR $(162 \mathrm{MHz}$, chloroform- $d$ ) $\delta$ (ppm): 123.27. HRMS. Calcd for $\left[\mathrm{C}_{24} \mathrm{H}_{19} \mathrm{NOPPd}\right]^{+} 474.0239$. 
Found 474.0239. Anal. Calcd for $\mathrm{C}_{24} \mathrm{H}_{19} \mathrm{NOPPdCl}$ : C, 56.49; H, $3.75 ; \mathrm{N}, 2.75$. Found: C, 56.48; H, 3.82; N, 2.83 .

Palladacycle (7b). Same method as 7a yielding $409 \mathrm{mg}$ of the expected product (7b) as a yellow solid in $22 \%$ yield. ${ }^{1} \mathrm{H}$ NMR (500 MHz, chloroform- $d$ ) $\delta$ (ppm): $9.16(\mathrm{~s}, 1 \mathrm{H}), 8.06-8.02(\mathrm{~m}$, $4 \mathrm{H}), 7.88(7.8,7.8 \mathrm{~Hz}, 1 \mathrm{H}), 7.72$ (d, $7.8 \mathrm{~Hz}, 1 \mathrm{H}), 7.54-7.46$ (m, $5 \mathrm{H}), 7.34$ (s. 1H), 7.29-7.26 (m, 2H), 7.15 (dd, 7.8, $7.8 \mathrm{~Hz}, 1 \mathrm{H})$, 6.96 (d, $7.8 \mathrm{~Hz}, 1 \mathrm{H}) .{ }^{13} \mathrm{C}$ NMR $(126 \mathrm{MHz}$, chloroform- $d$ ) $\delta(\mathrm{ppm}): 164.5\left(\mathrm{~d},{ }^{3} J_{P C}=3.0 \mathrm{~Hz}\right), 162.6\left(\mathrm{~d},{ }^{2} J_{P C}=10.0 \mathrm{~Hz}\right)$, $149.5,145.8,139.3,133.2\left(\mathrm{~d},{ }^{1} J_{P C}=55.2 \mathrm{~Hz}\right), 132.1\left(\mathrm{~d},{ }^{3} J_{P C}=2.5\right.$ $\mathrm{Hz}), 131.6\left(\mathrm{~d},{ }^{2} J_{P C}=14.8 \mathrm{~Hz}\right), 128.9\left(\mathrm{~d},{ }^{3} J_{P C}=11.9 \mathrm{~Hz}\right), 126.9$, $123.1\left(\mathrm{~d},{ }^{3} J_{P C}=3.4 \mathrm{~Hz}\right), 119.0,118.0,113.5\left(\mathrm{~d},{ }^{2} J_{P C}=17.2 \mathrm{~Hz}\right)$, 107.1. ${ }^{31} \mathrm{P}$ NMR (162 MHz, chloroform- $d$ ) $\delta$ (ppm): 155.3. HRMS. Calcd for $\left[\mathrm{C}_{23} \mathrm{H}_{17} \mathrm{NOPPdCl}\right]^{+}$460.0083. Found 460.0080. Anal. Calcd for $\mathrm{C}_{23} \mathrm{H}_{17} \mathrm{NOPPdCl}$ : C, 55.67; H, 3.45; N, 2.82. Found: C, 55.76; H, 3.58; N, 2.84 .

\section{Aldol condensation reaction}

Under an argon atmosphere, the palladium catalyst (0.01 eq.) was dissolved in DCM. The methylisocyanoacetate (1 eq.), benzaldehyde ( 1 eq.) and DIPEA (0.1 eq.) were added to the reaction vessel. The reaction was stirred at $\mathrm{rt}$ for $24 \mathrm{~h}$, then the reaction diluted with DCM $\left(10 \mathrm{~cm}^{3}\right)$, washed with $\mathrm{H}_{2} \mathrm{O}$ $\left(10 \mathrm{~cm}^{3}\right)$, and the organic layer collected using a hydrophobic frit. The solvent was removed in vacuo, and the mixture of products was obtained as a brown oil. ${ }^{1} \mathrm{H}$ NMR $(500 \mathrm{MHz}$, chloroform- $d$ ) $\delta 7.47-7.27(\mathrm{~m}, 12 \mathrm{H}), 5.75(\mathrm{~d}, J=11.1 \mathrm{~Hz}, 1 \mathrm{H}$, cis), $5.70(\mathrm{~d}, J=7.8 \mathrm{~Hz}, 1 \mathrm{H}$, trans), $5.10(\mathrm{dd}, 11.1,2.0 \mathrm{~Hz}, 1 \mathrm{H}$, cis), 4.65 (dd, 7.8, $2.2 \mathrm{~Hz}, 1 \mathrm{H}$, trans), 3.85 (s, 3H, trans), 3.21 (s, 3H, cis).

\section{Vinyl epoxide coupling}

The palladium catalyst ( $4 \mathrm{~mol} \%$ ), phenylboronic acid (1.2 eq.) and $\mathrm{Cs}_{2} \mathrm{CO}_{3}$ (2 eq.) were dissolved in 10:1 THF : $\mathrm{H}_{2} \mathrm{O}\left(3 \mathrm{~cm}^{3}\right)$. The 2-vinyloxirane was then added (1 eq.), and the reaction was stirred at $\mathrm{rt}$ for $24 \mathrm{~h}$. The solvent was removed in vacuo, dissolved in DCM $\left(5 \mathrm{~cm}^{3}\right)$, washed with $\mathrm{H}_{2} \mathrm{O}\left(5 \mathrm{~cm}^{3}\right)$, and separated using a hydrophobic frit. The solvent was then removed in vacuo yielding the mixture of linear and branched products. ${ }^{1} \mathrm{H}$ NMR (500 MHz, chloroform- $d$ ) $\delta 7.40-7.20(\mathrm{~m}, 10 \mathrm{H}), 6.03$ (ddd, $J=18.0,10.7,7.3 \mathrm{~Hz}, 1 \mathrm{H}$, branched), 5.91-5.85 (m, 1H, linear), 5.77-5.69 (m, 1H, linear), 5.24-5.19 (m, 2H, branched), 4.13 (s, 2H, linear), 3.88-3.81 (m, 2H, branched), 3.55 (dt, 7.3, $7.3 \mathrm{~Hz}, 1 \mathrm{H}$, branched), 3.40 (d, $6.7 \mathrm{~Hz}, 2 \mathrm{H}$, linear), 1.66 (s, $1 \mathrm{H}$, branched), 1.45 (s, 1H, linear). ${ }^{13} \mathrm{C}$ NMR (100 MHz, chloroform- $d$ ) $\delta 140.7$ (branched), 140.0 (linear), 138.3 (branched), 131.5 (linear), 130.3 (linear), 128.7 (branched), 128.5 (linear), 128.4 (linear), 126.9 (branched), 126.1 (linear), 117.0 (branched), 66.1 (branched), 63.5 (linear), 52.5 (branched), 38.6 (linear).

\section{Acknowledgements}

We would like to thank the University of Sussex for a studentship (GWR), Christopher Dadswell for the support and use of the GC equipment, and Johnson Matthey for the loan of palladium salts. We would also like to thank Dr Alaa Abdul-Sada at the University of Sussex and the EPSRC Mass Spectroscopy Facility (University of Swansea) for mass spectrometry services.

\section{Notes and references}

1 A. C. Cope and R. W. Siekman, J. Am. Chem. Soc., 1965, 87, 3272-3273.

2 C. J. Moulton and B. L. Shaw, J. Chem. Soc., Dalton Trans., 1976, 1020-1024.

3 W. A. Herrmann, C. Brossmer, K. Öfele, C.-P. Reisinger, T. Priermeier, M. Beller and H. Fischer, Angew. Chem., Int. Ed. Engl., 1995, 34, 1844-1848.

4 M. Beller, H. Fischer, W. A. Herrmann, K. Öfele and C. Brossmer, Angew. Chem., Int. Ed. Engl., 1995, 34, 18481849.

5 N. Selander and K. J. Szabó, Chem. Rev., 2011, 111, 20482076.

6 J. Dupont, C. S. Consorti and J. Spencer, Chem. Rev., 2005, 105, 2527-2572.

7 I. P. Beletskaya and A. V. Cheprakov, J. Organomet. Chem., 2004, 689, 4055-4082.

8 Palladacycles, ed. J. Dupont and M. Pfeffer, Wiley-VCH Verlag GmbH \& Co. KGaA, Weinheim, Germany, 2008.

9 R. B. Bedford, Chem. Commun., 2003, 1787-1796.

10 Pincer and Pincer-Type Complexes, ed. K. J. Szabó and O. F. Wendt, Wiley-VCH Verlag GmbH \& Co. KGaA, Weinheim, Germany, 2014.

11 D. Morales-Morales, Rev. Soc. Quim. Mex, 2004, 48, 338346.

12 The Chemistry of Pincer Compounds, ed. D. Morales-Morales and C. M. Jensen, Elsevier, Amsterdam, 2007.

13 R. Ratti, Can. Chem. Trans., 2014, 2, 467-488.

14 W.-H. Zhang, S. W. Chien and T. S. A. Hor, Coord. Chem. Rev., 2011, 255, 1991-2024.

15 D. M. Grove, G. van Koten, J. N. Louwen, J. G. Noites, A. L. Spek and H. J. C. Ubbels, J. Am. Chem. Soc., 1982, 104, 6609-6616.

16 G. Ebeling, M. R. Meneghetti, F. Rominger and J. Dupont, Organometallics, 2002, 21, 3221-3227.

17 I. Moreno, R. SanMartin, B. Ines, M. T. Herrero and E. Domínguez, Curr. Org. Chem., 2009, 13, 878-895.

18 P. Braunstein and F. Naud, Angew. Chem., Int. Ed., 2001, 40, 680-699.

19 H. Blaser, W. Brieden, B. Pugin, F. Spindler, M. Studer and A. Togni, Top. Catal., 2002, 19, 3-16.

20 A. Togni, C. Breutel, A. Schnyder, F. Spindler, H. Landert and A. Tijani, J. Am. Chem. Soc., 1994, 116, 4062-4066.

21 P. Steenwinkel, R. A. Gossage, T. Maunula, D. M. Grove and G. van Koten, Chem. - Eur. J., 1998, 4, 763-768.

22 A. Fleckhaus, A. H. Mousa, N. S. Lawal, N. K. Kazemifar and O. F. Wendt, Organometallics, 2015, 34, 1627-1634.

23 S. M. Khake, V. Soni, R. G. Gonnade and B. Punji, Dalton Trans., 2014, 43, 16084-16096. 
24 M. R. Eberhard, S. Matsukawa, Y. Yamamoto and C. M. Jensen, J. Organomet. Chem., 2003, 687, 185-189.

25 A. H. M. de Vries, J. M. C. A. Mulders, J. H. M. Mommers, H. J. W. Henderickx and J. G. de Vries, Org. Lett., 2003, 5, 3285-3288.

26 R. B. Bedford, C. S. J. Cazin, M. B. Hursthouse, M. E. Light and V. J. M. Scordia, Dalton Trans., 2004, 3864-3868.

27 M. Gagliardo, N. Selander, N. C. Mehendale, G. van Koten, R. J. M. Klein Gebbink and K. J. Szabó, Chem. - Eur. J., 2008, 14, 4800-4809.

28 J. Kjellgren, J. Aydin, O. A. Wallner, I. V. Saltanova and K. J. Szabó, Chem. - Eur. J., 2005, 11, 5260-5268.

29 G. W. Roffe, S. Boonseng, C. B. Baltus, S. J. Coles, I. J. Day, R. N. Jones, N. J. Press, M. Ruiz, G. J. Tizzard, H. Cox and J. Spencer, R. Soc. Open Sci., 2016, 3, 150656.

30 T. Kinzel, Y. Zhang and S. L. Buchwald, J. Am. Chem. Soc., 2010, 132, 14073-14075.

31 A. F. Abdel-Magid, K. G. Carson, B. D. Harris, C. A. Maryanoff, R. D. Shah and A. F. Abdel-Magid, J. Org. Chem., 1996, 61, 3849-3862.
32 R. J. Mattson, K. M. Pham, D. J. Leuck and K. A. Cowen, J. Org. Chem., 1990, 55, 2552-2554.

33 S. J. Loeb, G. K. H. Shimizu and J. A. Wisner, Organometallics, 1998, 17, 2324-2327.

34 J. Aydin, N. Selander and K. J. Szabó, Tetrahedron Lett., 2006, 47, 8999-9001.

35 X.-Q. Hao, Y.-N. Wang, J.-R. Liu, K.-L. Wang, J.-F. Gong and M.-P. Song, J. Organomet. Chem., 2010, 695, 82-89.

36 J.-L. Niu, X.-Q. Hao, J.-F. Gong and M.-P. Song, Dalton Trans., 2011, 40, 5135-5150.

37 J. S. Fossey and C. J. Richards, Organometallics, 2004, 23, 367-373.

38 H. P. Dijkstra, M. Q. Slagt, A. McDonald, C. A. Kruithof, R. Kreiter, A. M. Mills, M. Lutz, A. L. Spek, W. Klopper, G. P. M. van Klink and G. van Koten, Eur. J. Inorg. Chem., 2003, 830-838.

39 M. R. Eberhard, S. Matsukawa, Y. Yamamoto and C. M. Jensen, J. Organomet. Chem., 2003, 687, 185-189.

40 S. J. Coles and P. A. Gale, Chem. Sci., 2012, 3, 683689. 